\title{
LANGKAH-LANGKAH OPTIMASI PCR
}

\author{
Yuenleni $^{1}$ \\ ${ }^{1}$ Departemen Biokimia Fakultas Kedokteran, Kesehatan Masyarakat dan Keperawatan \\ Universitas Gadjah Mada. Email: yuenleni@ugm.ac.id,
}

Submisi: 20 Oktober 2018; Penerimaan 17 Juli 2019

\begin{abstract}
ABSTRAK
Salah satu teknik analisa genetika adalah PCR (Polymerase Chain Reaction). Sebelum dilakukan PCR dengan sampel penelitian, perlu dilakukan optimasi agar didapatkan komposisi dan kondisi PCR yang sesuai sehingga mendapatkan hasil PCR yang optimal. Seorang Pranata Laboratorium Pendidikan (PLP) ataupun teknisi laboratorium dalam mendampingi peneliti atau mengerjakan penelitian dengan PCR seharusnya mengetahui langkah-langkah yang dilakukan jika sampel dan reagen sudah siap.

Tulisan ini diharapkan mampu memberikan gambaran kepada PLP-teknisi laboratorium ataupun peneliti baru yang akan mengerjakan penelitian dengan PCR.

Optimasi PCR bisa dilakukan dengan variasi komposisi $P C R$ ataupun variasi tahapan PCR. Pada tulisan ini langkah-langkah PCR dijelaskan dengan contoh optimasi gena TCF7L2 (Transcription Factor 7-Like 2) dengan ukuran produk PCR 113 bp, optimasi ini dilakukan dengan variasi konsentrasi primer dan variasi tahapan PCR yaitu suhu annealing.

Penelitian ini dimulai dengan mengencerkan primer menjadi $100 \mathrm{uMol}$, kemudian membuat variasi konsentrasi primer yaitu 2,5 uMol, $5 \mathrm{uMol}$, dan $10 \mathrm{uMol}$. Suhu annealing (Ta) dihitung dari rata-rata suhu Melting (Tm) primer Forward dan Primer Reverse dikurangi 5, kemudian melakukan PCR dengan variasi primer dan variasi suhu annealing yaitu $47^{\circ} \mathrm{C}, 49{ }^{\circ} \mathrm{C}, 51^{\circ} \mathrm{C}$, dan $53^{\circ} \mathrm{C}$. Produk PCR di elektroforesis dan didokumentasikan hasilnya dengan Gel document dan gambar hasil elektroforesis dibandingkan secara visual.

Produk PCR pada masing-masing konsentrasi primer dan masing-masing suhu annealing didapatkan band yang tebal, terang dan sesuai ukuran (target) dan konsentrasi primer yang menghasilkan band yang optimal adalah 2,5 uMol, dan Suhu annealing yang yang optimal adalah $53^{\circ} \mathrm{C}$.
\end{abstract}

Kata kunci: Elektroforesis; PCR; Optimasi.

\section{PENDAHULUAN}

Salah satu teknik analisa genetika adalah PCR (Polymerase Chain Reaction). Sebelum dilakukan PCR dengan sampel penelitian, perlu dilakukan optimasi agar didapatkan komposisi dan kondisi PCR yang sesuai sehingga mendapatkan hasil PCR yang optimal. Seorang Pranata Laboratorium Pendidikan (PLP) ataupun teknisi laboratorium dalam mendampingi peneliti atau mengerjakan penelitian dengan PCR seharusnya mengetahui langkah-langkah yang dilakukan jika sampel dan reagen sudah siap.
Tulisan ini diharapkan mampu memberikan gambaran kepada PLPteknisi laboratorium ataupun peneliti baru yang akan mengerjakan penelitian dengan PCR.

PCR meliputi beberapa tahapan yaitu denaturasi, annealing dan ekstensi secara berulang, sedangkan komponen PCR meliputi Template DNA, primers, Taq DNA polymerase, PCR Buffer dan konsentrasi Mg2+, Nucleotides (dNTPs) (Fatchiyah, 2005).

Pada langkah optimasi kita dapat menvariasi tahapan PCR baik waktu ataupun suhu, dan komposisi PCR. 
Pada tulisan ini langkah-langkah PCR dijelaskan dengan contoh optimasi gena TCF7L2 (Transcription Factor 7-Like 2) dengan ukuran produk PCR 113 bp, optimasi ini dicontohkan dengan variasi konsentrasi primer dan variasi suhu annealing.

Variasi suhu annealing didapatkan dengan perhitungan rata-rata suhu melting $(\mathrm{Tm})$ primer Forward dan Primer Reverse kemudian dikurangi 5, karena suhu annealing biasanya $5{ }^{\circ} \mathrm{C}$ di bawah $\mathrm{Tm}$ primer yang sebenarnya. Pada mesin PCR variasi suhu annealing ini dilakukan dengan memasukkan program gradient.

Produk PCR yang dihasilkan kemudian dielektroforesis. Hasil elektrfororesis ini dianalisa dengan membandingkan ketebalan band secara visual. Band yang optimal yang dimaksud pada penelitian ini adalah band yang tebal, tunggal/single dan sesuai ukuran target.

Konsentrasi primer dan suhu annealing yang menghasilkan band yang optimal inilah yang selanjutnya digunakan untuk PCR pada sampel penelitian.

\section{TUJUAN}

Tujuan penelitian ini adalah memberikan contoh langkah-langkah optimasi PCR sehingga didapatkan

a. Konsentrasi Primer yang menghasilkan produk PCR dengan band yang optimal

b. Suhu annealing yang menghasilkan produk PCR dengan band yang optimal

\section{METODE}

\section{Alat}

a. Neraca analitik

b. Microwave atau hot plate

c. Pipet mikro 0.5-10 uL, 10-100uL, 100-1000uL
d. Cetakan Gel
e. Mesin Elektroforesis
f. Gel Document
g. Pena marker

\section{Bahan}
a. Agarose
b. $\mathrm{ddH} 2 \mathrm{O}$
c. Gotaq green mastermix
d. Ladder
e. Yellowtips, Blue tips, white tips
f. Microtube $1.5 \mathrm{cc}, 0,2 \mathrm{cc}$
g. TE Buffer
h. 0,5 X TBE Buffer

\section{Cara Kerja}

1. Mengencerkan primer TCF7L2Forward 5-GAG AGC TAA GCA CTT TTT AGG TA-3 menjadi konsentrasi 100uMol Tm $52.3^{\circ} \mathrm{C}$

2. Mengencerkan primer TCF7L2Reverse 5-CTG ACA TTG ACT AAG TTA CTT GC-3 menjadi konsentrasi 100 uMol Tm $51.6^{\circ} \mathrm{C}$

3. Penambahan TE buffer sebagai pelarut sesuai dengan keterangan datasheet primer dengan mengalikan 10 pada nmole.

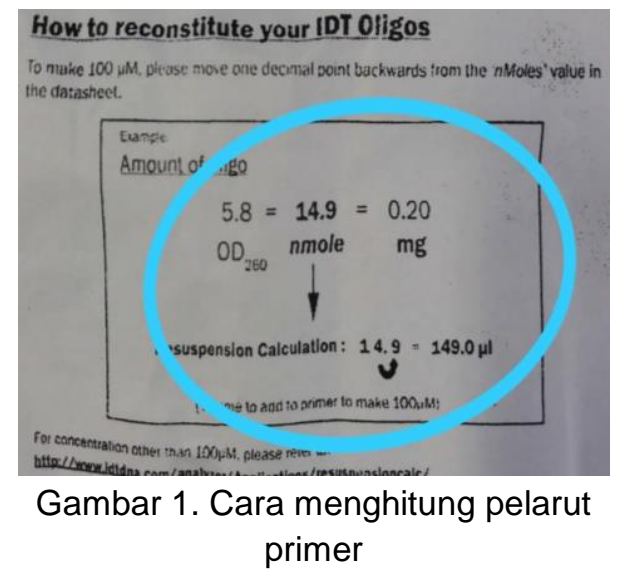

Untuk primer TCF7L2-Forward, TE Buffer yang ditambahkan adalah 283 Ul. Untuk primer TCF7L2 -Reserve,TE Buffer yang ditambahkan adalah $273 \mathrm{uL}$ 


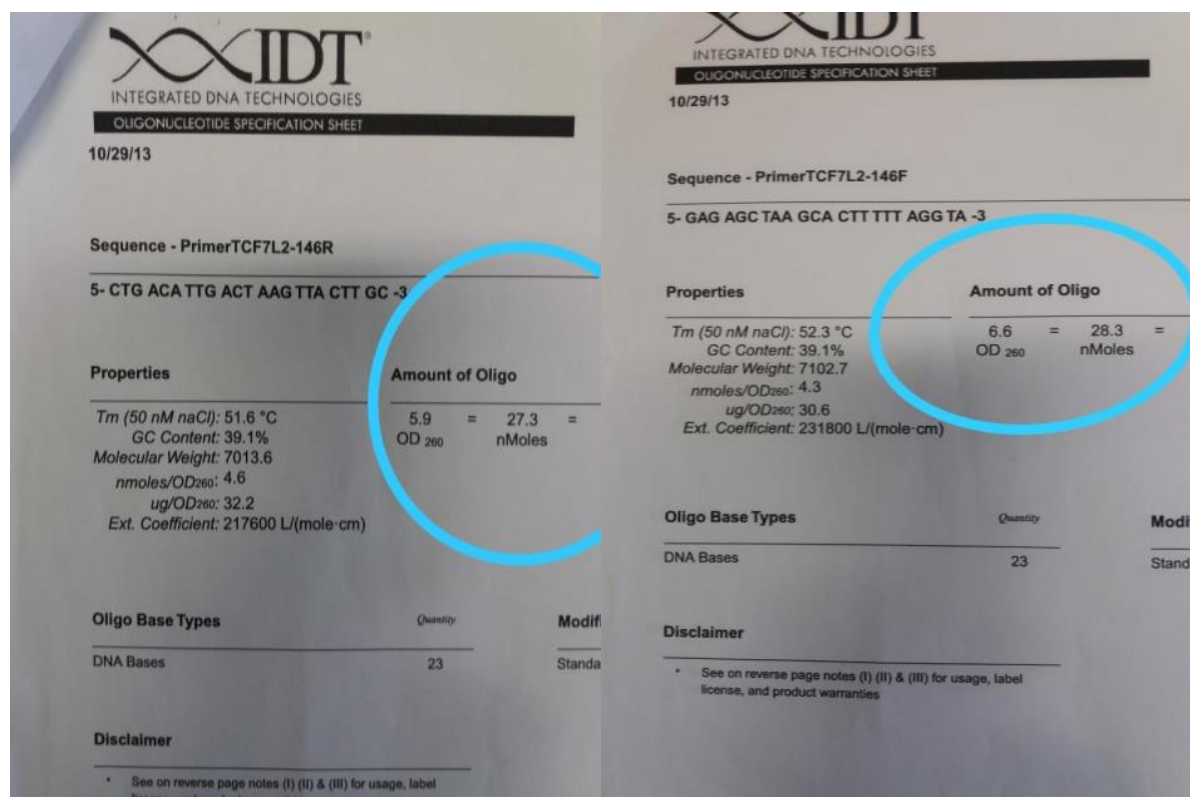

Gambar 2. Datasheet dari primer TCF7L2

Pengenceran primer akan lebih bagus jika dengan tips yang berfilter untuk meminimalisir kontaminasi. Setelah dilarutkan sebaiknya di buat aliquot beberapa tube sehingga stok tidak keluar masuk dari penyimpanan. Penyimpanan primer yang telah dilarutkan pada suhu $-20^{\circ} \mathrm{C}$.

1) Membuat variasi primer $2.5 \mathrm{uMol}$, 5 uMol, dan 10 uMol dengan mengencerkan primer stok $100 \mathrm{uMol}$

a) Konsentrasi primer $10 \mathrm{uMol}$ : pipet $10 \mathrm{uL}$ primer $100 \mathrm{uMol}$ ditambahkan $90 \mathrm{uL}$ ddH2O

b) Konsentrasi primer $5 \mathrm{uMol}$ : pipet $50 \mathrm{uL}$ primer $10 \mathrm{uMol}$ ditambahkan 50 uL ddH2O

c) Konsentrasi primer $2,5 \mathrm{uMol}$ : pipet $50 \mathrm{uL}$ primer $5 \mathrm{uMol}$ ditambahkan $50 \mathrm{uL}$ ddH2O

Pada tube dituliskan nama gen dan konsentrasi masing-masing dengan pena marker

2) Membuat campuran PCR (PCR mixture)

Komposisi sebagai berikut :

Gotaq mastermix $15 \mathrm{uL}$ ddH2O 9 uL

Primer Forward 1uL
Primer Reverse 1uL

DNA template $23,5 \mathrm{ug} / \mathrm{ml}, 4 \mathrm{uL}$

Total volume $30 \mathrm{uL}$

Tuliskan kode pada microtube dengan pena marker.

Pada proses pembuatan PCR mixture sebaiknya reagen untuk PCR ini sebaiknya di letakkan di atas es.

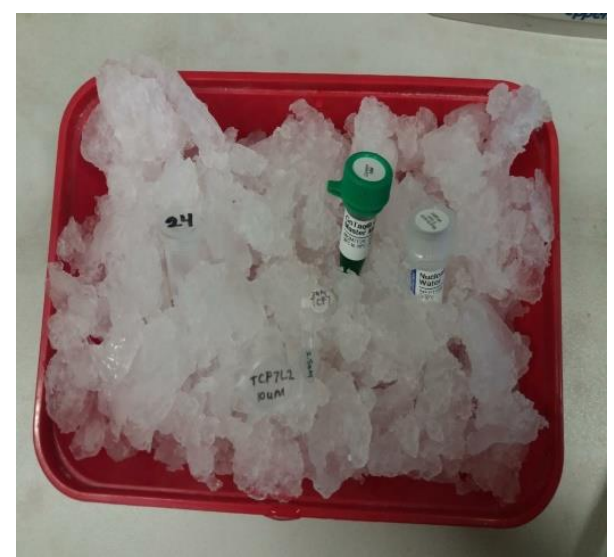

Gambar 3. Reagen dan sampel yang diletakkan pada es

Campuran reagen tidak perlu di vortex atau dicampur dengan pipetting cukup di-spindown, agar sampel dan reagen terkumpul di ujung microtube dengan alat seperti dibawah ini. 

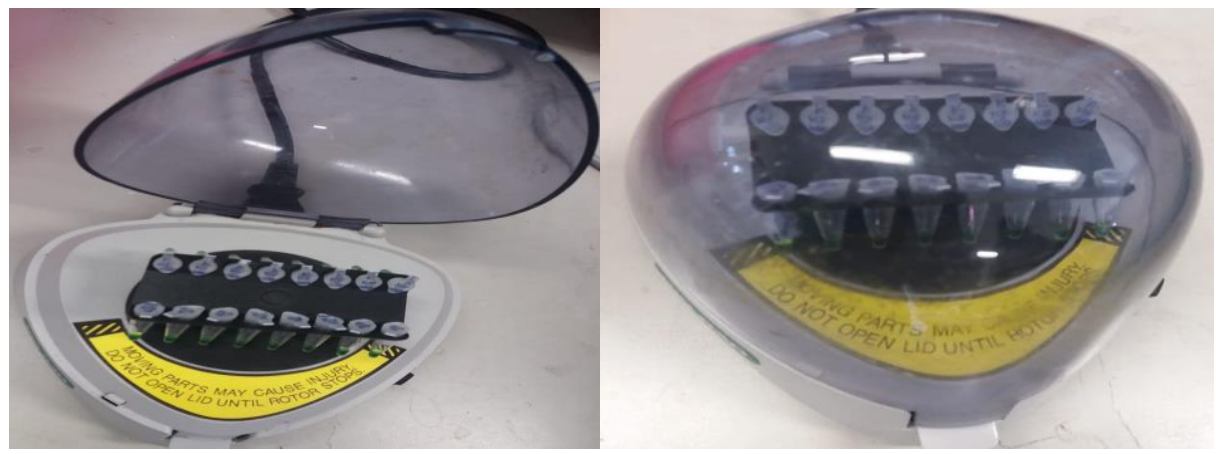

Gambar 4: Alat Spindown untuk campuran PCR

3) Mensetting program pada mesin PCR

a) Pre denaturasi $95{ }^{\circ} \mathrm{C}$ selama 7 menit

b) Denaturasai $95{ }^{\circ} \mathrm{C}$ selama 45 detik, annealing $47{ }^{\circ} \mathrm{C}-53{ }^{\circ} \mathrm{C}$ (gradient) selama 45 detik, Extensi $72{ }^{\circ} \mathrm{C}$ selama 45 detik ulangi sebanyak 35 siklus

c) $72^{\circ} \mathrm{C}$ selama 7 menit

d) $12 \mathrm{C} \infty$

Setiap mesin PCR memiliki cara pengoperasian yang berbeda, mintalah bantuan kepada petugas penanggung jawab mesin untuk pertama kali pengoperasian PCR.

4) Pembuatan Agarose

a) Timbang 2 gram agarose,

b) Tambahkan 100ml TBE 0,5 $\mathrm{X}$

c) Gojok, dan panaskan menggunakan microwave selama 2 menit sampai larutan terlihat jernih

d) Tunggu larutan mencapai suhu $50^{\circ} \mathrm{C}-60^{\circ} \mathrm{C}$

e) Tambahkan 2 uL florosafe, campur

f) Tuang ke dalam cetakan gel yang sudah terpasang

g) Tunggu agarose gel mengeras, kurang lebih 30 menit

5) Elektrfoforesis Hasil PCR (produk PCR)

a) Masukkan buffer TBE 0.5X pada tangki mesin elektroforesis b) Masukkan agarose gel ke dalam tangki elektroforesis sampai agarose tenggelam

c) Masukkan 3 uL Ladder pada sumuran

d) Masukkan 5 ul Produk PCR

e) Tutup tangki mesin elektroforesis

f) Catat urutan sampel yang dimasukkan

g) Setting program $100 \mathrm{~V}$ selama 25 menit

h) Matikan mesin elektroforesis, buka tutup tangki

i) Ambil gel, Foto dengan menggunakan gel document

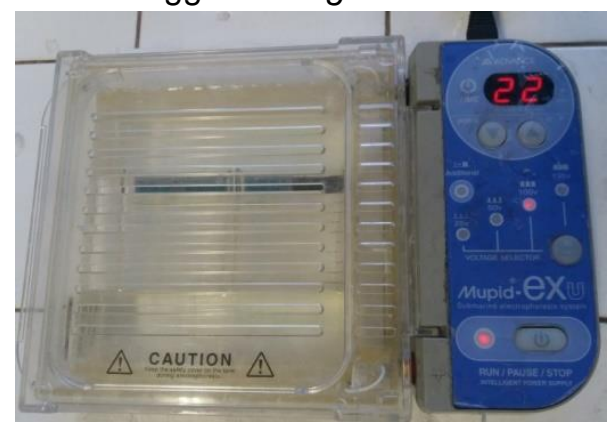

Gambar 5. Contoh mesin elektroforesis

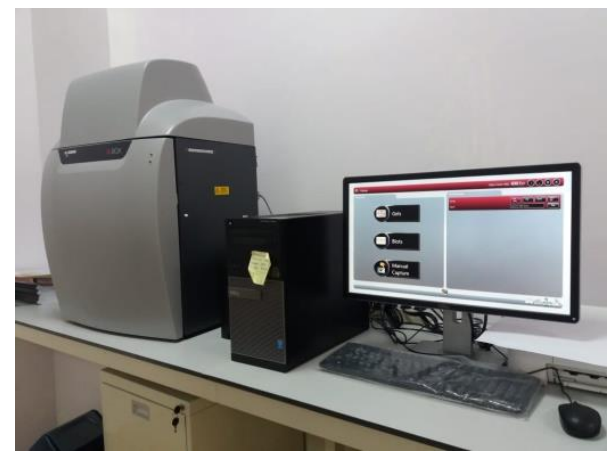

Gambar 6. Contoh alat Gel Document 


\section{HASIL DAN PEMBAHASAN \\ Hasil}

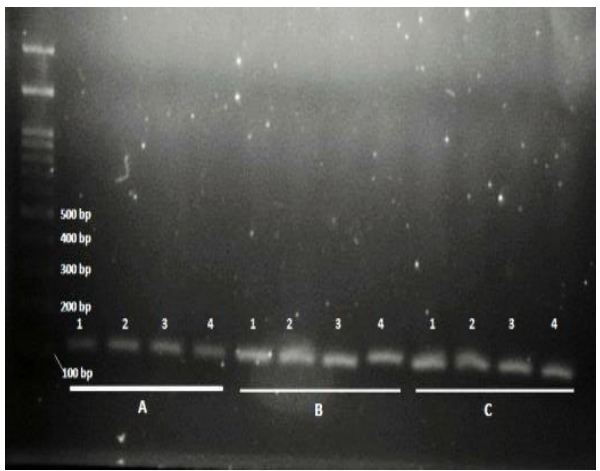

Gambar 7. Hasil elektroforesis, A

Produk PCR dengan konsentrasi primer 2,5 uMol, B. Produk PCR dengan konsentrasi primer 5 uMol,B. Produk PCR dengan konsentrasi primer 10 uMol, 1.Produk PCR dengan suhu annealing $47^{\circ} \mathrm{C}, 2$. Produk PCR dengan suhu annealing $49^{\circ} \mathrm{C}, 3$. Produk PCR dengan suhu annealing $51^{\circ} \mathrm{C}$, 4.Produk PCR dengan suhu annealing $53^{\circ} \mathrm{C}$

Pada gambar 7, hasil elektroforesis gena TCF7L2 didapatkan band pada $113 \mathrm{bp}$. Produk PCR pada setiap konsentrasi primer yaitu $2.5 \mathrm{uMol}$, 5 uMol dan $10 \mathrm{uMol}$ band terlihat jelas. Begitu juga pada tiap-tiap suhu annealing yaitu $47^{\circ} \mathrm{C}, 49^{\circ} \mathrm{C}, 51^{\circ} \mathrm{C}$ dan $53^{\circ} \mathrm{C}$ band juga terlihat jelas. Ladder juga teripsah dengan baik namun demikian pada ladder dengan ukuran 100 bp dan 200 bp terlihat kurang jelas.

\section{Pembahasan}

Pada optimasi ini digunakan produk DNA dengan konsentrasi 23,5 $\mathrm{ug} / \mathrm{ml}$. Pada elektroforesis hasil PCR, yang dimaksud band yang optimal adalah band yang tebal, bersih dan sesuai ukuran (target). Gambar 7, menunjukkan pada semua konsentrasi primer yaitu $2.5 \mathrm{uMol}, 5 \mathrm{uMol}$ dan 10 uMol didapatkan gambar pita/band yang jelas dan sesuai target, meskipun band pada ladder dengan ukuran 100 bp kurang jelas. Menurut Padmalatha, konsentrasi primer yang terlalu rendah atau terlalu tinggi dapat menyebabkan tidak terjadinya amplifikasi. Semakin tinggi konsentrasi primer bisa menyebabkan band yang tebal tetapi kadang diikuti band yang tidak spesifik (unspecific band).

Pada semua variasi suhu annealing $47{ }^{\circ} \mathrm{C}, 49^{\circ} \mathrm{C}, 51{ }^{\circ} \mathrm{C}$ dan $53^{\circ} \mathrm{C}$ didapatkan gambar band yang jelas. Pada suhu annealing yang terlalu rendah, non specific band akan teramplifikasi yang menyebabkan multiple band pada hasil elektroforesis. Dan jika suhu annealing terlalu tinggi kadang hasil kurang jelas (Rychlik, dkk 1990).

Hasil optimasi sebaiknya dicobakan untuk beberapa sampel penelitian dulu, tidak langsung pada seluruh sampel penelitian, karena konsentrasi DNA yang dioptimasi bisa saja berbeda dengan konsentrasi produk DNA pada seluruh sampel penelitian.

Langkah optimasi ini selalu dilakukan untuk setiap gena yang akan di PCR karena kondisi sampel, reagen dan alat-alat yang ada pada setiap laboratorium berbeda-beda.

\section{KESIMPULAN DAN SARAN}

\section{Kesimpulan}

1) Konsentrasi primer yang menghasilkan band yang optimal adalah 2,5 uMol,

2) Suhu annealing yang menghasilkan band yang optimal adalah $53^{\circ} \mathrm{C}$.

\section{Saran}

1) Perlu dicoba elektroforesis dengan 50 bp DNA Ladder sehingga menghasilkan band yang jelas sampai ukuran target $113 \mathrm{bp}$.

2) Optimasi selain sesuai yang dicontohkan juga bisa dilakukan pada komposisi dan tahapan PCR yang lain. 


\section{Daftar Pustaka}

Fatchiyah, 2005, PCR:Dasar teknik amplifikasi DNA dan aplikasinya.

http://fatchiyah lecture.ub.ac.id/teachingresponsibility/general/

Patmalatha,K \& Prasad, MNV, 2006. Optimization of DNA Isolation \&PCR protocol for RAPD Analisys of Selected Medicinal and aromatic Plant of
Conservation Concern from Peninsular India. African Journal Biotechnology S. p.230-234

Rychlik W, WJ Spencer, RE Rhoads, 1990.Optimization of The Annealing Temperature for DNA amplification in vitro, Nucleic acids Research, Vol.18 No.21 P.6409 